\title{
Phenotypic and Genotypic Comparison of Vibrio in Seawater Fish from Batam and Mataram, Indonesia
}

\author{
Rio Aditya Kurniawan ${ }^{1}$ and Kurniasih ${ }^{2}$ \\ 1. Ministry of Marine Affairs and Fisheries Republic of Indonesia, Fish Quarantine and Inspection Agency, Jayapura, Papua 99352, \\ Indonesia \\ 2. Faculty of Veterinary Medicine, Gadjah Mada University, Yogyakarta 55281, Indonesia
}

\begin{abstract}
Grouper and snapper are the potential fishery commodity in Indonesia with a high economic value, as well as an export commodity. A common disease in grouper and snapper aquaculture is vibriosis. Vibriosis is a disease caused by bacteria of the genus Vibrio. The aim of study was to compare between phenotypic and genotypic identification of Vibrio isolated from Batam and Mataram, Indonesia. Bacteria were isolated from anterior kidney and eye of fish, then grown in thiosulfate-citrate-bile salts-sucrose (TCBS) and incubated in room temperature $\left(25-28{ }^{\circ} \mathrm{C}\right)$ for $24 \mathrm{~h}$, and identified using morphology and biochemical test. Bacterial isolates were extracted, amplified and sequenced on 16S rRNA region. Phylogenetic tree of bacteria was constructed using neighbor-joining and maximum-parsimony methods. The phenotypic identification was found six isolates of Vibrio from Batam, such as $V$. alginolyticus, $V$. carchariae, $V$. damselae, $V$. fluvialis, $V$. furnissii and $V$. parahaemolyticus. Three isolates were found from Mataram, such as V. alginolyticus, V. carchariae and $V$. fluvialis. Blast analysis showed isolates of $V$. alginolyticus_btm and $V$. carchariae_btm homolog to V. parahaemolyticus strain DAHMV3; isolates of $V$. damselae_btm and $V$. alginolyticus_mtr homolog to $V$. neocaledonicus strain MS1; isolates of V. parahaemolyticus_btm and V. furnisii_btm homolog with Photobacterium damselae subsp. damselae strain: $04 \mathrm{Ya} 311$ and isolate of $V$. fluvialis_mtr homolog to V. azureus strain MMRF532, respectively. All phenotypic identification was not supported by molecular identification on 16S rRNA region. It was suggested that phenotypic identification should be supported by molecular examination, especially in identification of Vibrio species.
\end{abstract}

Key words: Vibrio, phenotype, genotype, 16S rRNA.

\section{Introduction}

Aquaculture development in Indonesia has been accelerated and now considered as an important sector in supporting economic development. The Vibrionaceae is a large family of gram-negative maprobacteria. They live in a vast range of aquatic environments as pathogens of aquatic organisms, such as Vibrio was classified as pathogen in snapper and grouper [1]. Several species of Vibrio include $V$. alginolyticus, $V$. anguillarum, $V$. charcariae, $V$. damselae, V. ordalli and V. vulnificus [2]. Recently, identification and detection of pathogens were carried out by observation of clinical signs, history of disease incidence in farms, characteristic morphology,

Corresponding author: Kurniasih, professor, research fields: veterinary pathology and aquatic animal disease. physiology and biochemistry of bacteria. This method has an important role as a preliminary study, while on the other hand, it is not able to determine the phylogeny of its bacteria and its expression is influenced by environmental factors. But, these restrictions can be solved by molecular methods [3]. The phenotypic features were used for understanding of the ecology of Vibrio, however, the traditional phenotypic characterization of Vibrio has been expensive and restricted in scope to a limited number of features [4].

Generally, the method for definitive identification of Vibrio was based on authoring standard references, such as Ref. [5]. This method is time-consuming, tedious and expensive, while it is reasoned that the molecular methods might provide more rapid and sensitive alternative for differentiating among Vibrio 
isolates. Thus, the study was aimed to compare between phenotypic and genotypic identification of Vibrio isolated from Batam and Mataram, Indonesia.

\section{Materials and Methods}

\subsection{Isolation and Identification}

Vibrio was isolated from anterior kidney and eye of naturally infected fish from Batam and Mataram. The sample number is 15 fish, consisting of six cantang grouper (Epinephelus sp.), four humpback grouper (Chromileptis altivelis), three snapper (Lates calcarifer) and two abalone (Haliotis sp.). The bacteria were grown in thiosulfate-citrate-bile salts-sucrose (TCBS, Oxoid) agar and incubated in room temperature $\left(25-28^{\circ} \mathrm{C}\right)$ for $24 \mathrm{~h}$. Identification was based on morphology and biochemical tests were according to Refs. [5, 6].

\subsection{Molecular Analysis}

Isolates of Vibrio from Batam and Mataram were extracted using DNA extraction kit (DNeasy ${ }^{\circledR}$, Qiagen) with lysozyme to break down the bacterial cell walls. The primers used were $9 \mathrm{~F}$ (5'-GAGTTTGATCCTGGCTCAG-3') and 1114R (5'-CCCGGAACCCAAAAACTTTG-3') as reverse primer and 765R (5’-CTGTTTGCTCCCCACGCTTTC-3') as internal primer [7].

Amplification cycle condition was pre-denaturation at $94{ }^{\circ} \mathrm{C}$ for $5 \mathrm{~min}\left(94{ }^{\circ} \mathrm{C}\right.$ for $30 \mathrm{~s}$ denaturation, annealing at $53^{\circ} \mathrm{C}$ for $45 \mathrm{~s}$, extension at $72^{\circ} \mathrm{C}$ for $90 \mathrm{~s}$ ) by 30 cycles and a final extension at $72^{\circ} \mathrm{C}$ for $5 \mathrm{~min}$.

A similarity search with $16 \mathrm{~S}$ rRNA sequence was performed with 16S rRNA sequences available in GenBank/EMBL/DDBJ databases using basic local alignment search tool (BLAST) algorithm [8]. The sequence results were aligned with CLUSTAL W multiple sequence alignment program version 1.8 [9] and evolutionary tree was created using the neighbor-joining and maximum-parsimony method with MEGA 6 [10].

\section{Results and Discussion}

\subsection{Phenotypic Result}

The morphology, physiology and biochemical properties from all samples were observed and indicated as gram-negative, rod-shaped and motile, producing catalase and oxidase, fermentative and aerobic. According to Refs. [5, 6], all samples were identified to the genus Vibrio. Identification of Vibrio from Batam were found six isolates of Vibrio, namely, $V$. alginolyticus, V. carchariae, V. damselae, V. furnisii, V. fluvialis and $V$. parahaemolyticus, and from Mataram were found three isolates of Vibrio, namely, $V$. alginolyticus, $V$. carchariae and $V$. fluvialis, respectively. The results of phenotypic analysis were described in Tables 1 and 2.

\subsection{Molecular Results}

The polymerase chain reaction (PCR) results of isolates from Batam and Mataram in 16S rRNA region showed 1,100 bp of bands (Fig. 1). The DNA sequences of isolates from Batam and Mataram were confirmed within the world gen database (BLAST). $V$. alginolyticus_btm and $V$. carchariae_btm were homologous with $V$. parahaemolyticus strains DAHMV with $100 \%$ homology rate. $V$. damselae_btm and $V$. alginolyticus_mtr were homologous to $V$. neocaledonicus strain MS1 with 100\% homology rate. Isolate V. parahaemolyticus_btm and V. furnisii_btm were homologous to Photobacterium damselae subsp. damselae strain: 04Ya311 with $100 \%$ homology rate and $V$. fluvialis_mtr homologous to $V$. azureus strain MMRF532 with of $99 \%$ of homology rate, respectively (Table 3).

Phylogenetic tree with neighbor-joining and maximum-parsimony method (Figs. 2 and 3) showed $V$. carchariae_btm, $V$. alginolyticus_btm and $V$. fluvialis_mtr closely related to $V$. alginolyticus NBRC15630 that was similar with $V$. alginolyticus ATCC17749 and isolated from Atlantic horse mackerel (Trachurus trachurus) from Shandong, China [11]. 
Table 1 Morphometric and biochemical characters of Vibrio isolated from Batam based on Refs. [4, 5].

\begin{tabular}{|c|c|c|c|c|c|c|}
\hline Characters test & Isolate A & Isolate D & Isolate E & Isolate $\mathrm{F}$ & Isolate I & Isolate $\mathrm{J}$ \\
\hline $\begin{array}{l}\text { Colony color in thiosulfate-citrate-bile } \\
\text { salts-sucrose (TCBS) }\end{array}$ & Yellow & Green & Green & Yellow & Yellow & Green \\
\hline Motility & + & + & + & + & + & + \\
\hline Aerob & + & + & + & + & + & + \\
\hline Catalase & + & + & + & + & + & + \\
\hline Oxydase & + & + & + & + & + & + \\
\hline Carbohydrate & $\mathrm{F}$ & $\mathrm{F}$ & $\mathrm{F}$ & $\mathrm{F}$ & $\mathrm{F}$ & F \\
\hline TSIA & $\mathrm{A} / \mathrm{K}$ & $\mathrm{A} / \mathrm{A}$ & $\mathrm{A} / \mathrm{A}$ & $\mathrm{A} / \mathrm{A}$ & $\mathrm{A} / \mathrm{A}$ & $\mathrm{A} / \mathrm{A}$ \\
\hline $\mathrm{H}_{2} \mathrm{~S}$ & + & - & + & - & + & - \\
\hline Gas production & + & + & + & - & + & - \\
\hline Growth in $4 \% \mathrm{NaCl}$ & + & + & + & + & + & + \\
\hline Growth in $6 \% \mathrm{NaCl}$ & + & + & + & + & + & + \\
\hline Growth in $8 \% \mathrm{NaCl}$ & + & - & - & - & - & - \\
\hline Growth in $10 \% \mathrm{NaCl}$ & + & - & - & - & - & - \\
\hline Urea & - & + & - & - & - & - \\
\hline DNase & + & + & + & + & + & + \\
\hline Indol & + & + & + & - & + & - \\
\hline Methyl red & + & + & + & + & + & + \\
\hline Voges-Proskaeur & + & - & - & - & - & - \\
\hline Simmon citrate & + & + & + & + & + & + \\
\hline Glucose & + & + & + & - & + & + \\
\hline Lactose & - & - & + & - & - & - \\
\hline Sorbitol & + & + & + & - & - & - \\
\hline Raffinose & - & - & + & - & - & - \\
\hline Inulin & + & + & + & + & + & + \\
\hline Aesculin & - & - & - & - & - & - \\
\hline Sucrose & + & + & - & + & + & + \\
\hline Identification of isolate & $\begin{array}{l}\text { Vibrio } \\
\text { alginolyticus }\end{array}$ & $\begin{array}{l}\text { Vibrio } \\
\text { carchariae }\end{array}$ & $\begin{array}{l}\text { Vibrio } \\
\text { damselae }\end{array}$ & $\begin{array}{l}\text { Vibrio } \\
\text { fluvialis }\end{array}$ & $\begin{array}{l}\text { Vibrio } \\
\text { furnissii }\end{array}$ & $\begin{array}{l}\text { Vibrio } \\
\text { parahae-molyticus }\end{array}$ \\
\hline
\end{tabular}

TSIA: triple sugar iron agar; +: positive test result; -: negative test result; F: fermentative; A/A: glucose-sucrose-lactose fermentation; $\mathrm{A} / \mathrm{K}$ : glucose fermentation and non lactose-sucrose fermentation.

V. furnisii_btm and V. parahaemolyticus_btm were closely related to Vibrio sp. from Australia.

$V$. damselae_btm and V. alginolyticus_mtr were closely related to $V$. parahaemolyticus CM12 from India that was isolated from coral (Acropora digitifera) from Mannar gulf, India [12]. Recently, the pathogen bacteria in coral are $V$. alginolyticus, $V$. parahemolyticus, $V$. shiloi, $V$. coralilyticus, $V$. natriegen and $V$. harveyi [13]. However, V. alginolyticus from Batam and Mataram was different or there was genetic variation. $V$. fluvialis from Mataram genetically homologous to $V$. azureus strains MMRF352 (accession number KF418757.1) was derived from the marine yellow sponge, which causes the disease in coral known as the "yellow band disease" [14]. $V$. furnisii_btm and $V$. parahaemolyticus_btm closely were related to Vibrio sp. from Australia derived from aquatic animals in Australia, which were used in the taxonomic study of Vibrionaceae family [15]. Isolates of $V$. damselae from Batam and $V$. alginolyticus from Mataram were homologous to $V$. neocaledonicus (accession number KJ841877.1) that was characterized from secretion exopolysaccharide (EPS) of seawater bacteria [16]. $V$. alginolyticus_btm and $V$. charchariae_btm were homologous to V. parahaemolyticus strains DAHMV3 (accession number KC476545.1) that was used for screening and characterization of biofilms and probiotics derived from water [17]. 

from Batam and Mataram, Indonesia

Table 2 Morphometric and biochemical characters of Vibrio isolated from Mataram.

\begin{tabular}{|c|c|c|c|c|c|c|}
\hline Characters test & $\begin{array}{l}\text { Vibrio } \\
\text { alginolyticus }\end{array}$ & $\begin{array}{l}\text { Vibrio } \\
\text { fluvialis }\end{array}$ & $\begin{array}{l}\text { Vibrio } \\
\text { carchariae }^{*}\end{array}$ & Isolate L & Isolate $\mathrm{M}$ & Isolate $\mathrm{N}$ \\
\hline $\begin{array}{l}\text { Thiosulfate-citrate-bile } \\
\text { salts-sucrose (TCBS) }\end{array}$ & Yellow & Yellow & Yellow/Green & Yellow & Green & Yellow \\
\hline Motility & + & + & + & + & + & + \\
\hline Aerob & + & + & + & + & + & + \\
\hline Catalase & + & + & + & + & + & + \\
\hline Oxydase & + & + & + & + & + & + \\
\hline Carbohydrate & $\mathrm{F}$ & $\mathrm{F}$ & $\mathrm{F}$ & $\mathrm{F}$ & $\mathrm{F}$ & $\mathrm{F}$ \\
\hline TSIA & $\mathrm{A} / \mathrm{K}$ & $\mathrm{A} / \mathrm{A}$ & $\mathrm{A} / \mathrm{A}$ & $\mathrm{A} / \mathrm{K}$ & $\mathrm{A} / \mathrm{A}$ & $\mathrm{A} / \mathrm{A}$ \\
\hline $\mathrm{H}_{2} \mathrm{~S}$ & + & - & - & + & - & - \\
\hline Gas production & d & d & d & + & + & - \\
\hline Indol & + & d & + & + & + & + \\
\hline Methyl red & + & + & + & + & + & + \\
\hline Voges-Proskaeur & + & - & - & - & - & - \\
\hline Simmon citrate & + & + & + & + & + & + \\
\hline Growth in $4 \% \mathrm{NaCl}$ & + & + & + & + & + & + \\
\hline Growth in $6 \% \mathrm{NaCl}$ & + & + & + & + & + & + \\
\hline Growth in $8 \% \mathrm{NaCl}$ & + & - & + & - & - & - \\
\hline Growth in $10 \% \mathrm{NaCl}$ & + & - & - & - & - & - \\
\hline Urea & d & - & + & - & + & - \\
\hline DNase & + & + & + & + & + & + \\
\hline Glucose & + & d & + & + & + & + \\
\hline Lactose & - & - & - & - & - & - \\
\hline Sorbitol & + & - & d & - & - & - \\
\hline Raffinose & - & - & - & - & - & - \\
\hline Inulin & + & + & + & + & + & + \\
\hline Aesculin & - & - & - & - & - & - \\
\hline Sucrose & d & + & + & + & + & + \\
\hline Identification of isolate & & & & $\begin{array}{l}\text { Vibrio } \\
\text { alginolyticus } \\
\end{array}$ & $\begin{array}{l}\text { Vibrio } \\
\text { carchariae }\end{array}$ & Vibrio fluvialis \\
\hline
\end{tabular}

TSIA: triple sugar iron agar; +: positive test result; -: negative test result; A/A: glucose-sucrose-lactose fermentation; A/K: glucose fermentation and non lactose-sucrose fermentation; d: different reactions given by different strain or positive reaction often delayed; *: based on Refs. [4, 5].
12
345
$\begin{array}{lll}6 & 7 & 8\end{array}$
$9 \quad 10$

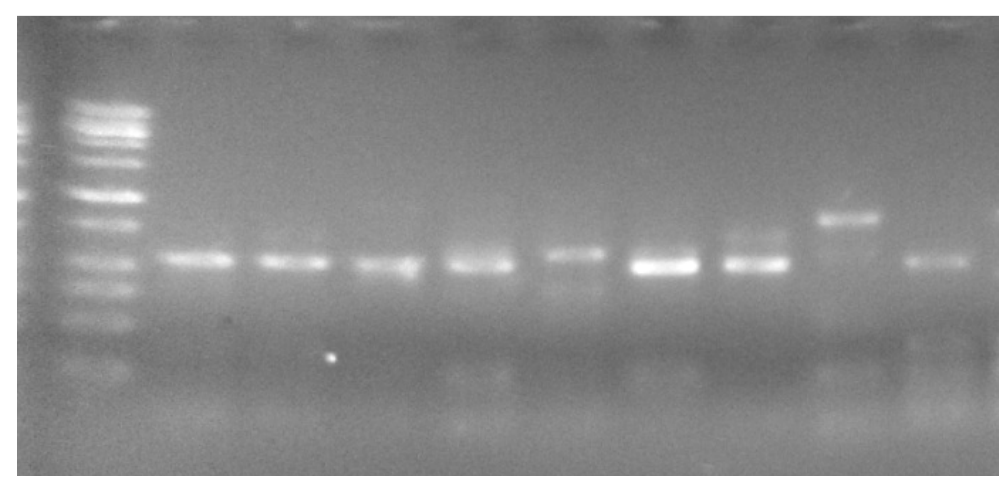

Fig. 1 PCR product of Vibrio isolated from Batam and Mataram.

Lane 1: marker; 2: V. alginolyticus; 3: V. carchariae; 4: V. damselae; 5: V. furnisii; 6: V. fluvialis; 7: V. parahaemolyticus; 8: V. alginolyticus Mataram; 9: V. carchariae Mataram; 10: V. fluvialis Mataram. 
from Batam and Mataram, Indonesia

Table 3 Molecular characteristic of isolates and their homology to gene bank references.

\begin{tabular}{llll}
\hline No. & Phenotype identification & Genotype identification & Homology \\
\hline 1 & Vibrio alginolyticus_btm & Vibrio parahaemolyticus strain DAHMV3 & $100 \%$ \\
2 & Vibrio carchariae_btm & Vibrio parahaemolyticus strain DAHMV3 & $100 \%$ \\
3 & Vibrio damselae_btm & Vibrio neocaledonicus strain MS1 & $100 \%$ \\
4 & Vibrio alginolyticus_mtr & Vibrio neocaledonicus strain MS1 & $100 \%$ \\
5 & Vibrio furnisii_btm & Photobacterium damselae subsp. damselae strain: 04Ya311 & $100 \%$ \\
6 & Vibrio parahaemolyticus_btm & Photobacterium damselae subsp. damselae strain: 04Ya311 & $100 \%$ \\
7 & Vibrio fluvialis_mtr & Vibrio azureus strain MMRF532 & $99 \%$ \\
\hline
\end{tabular}

btm: a code that refer to a region (Batam); mtr: a code that refer to a region (Mataram).

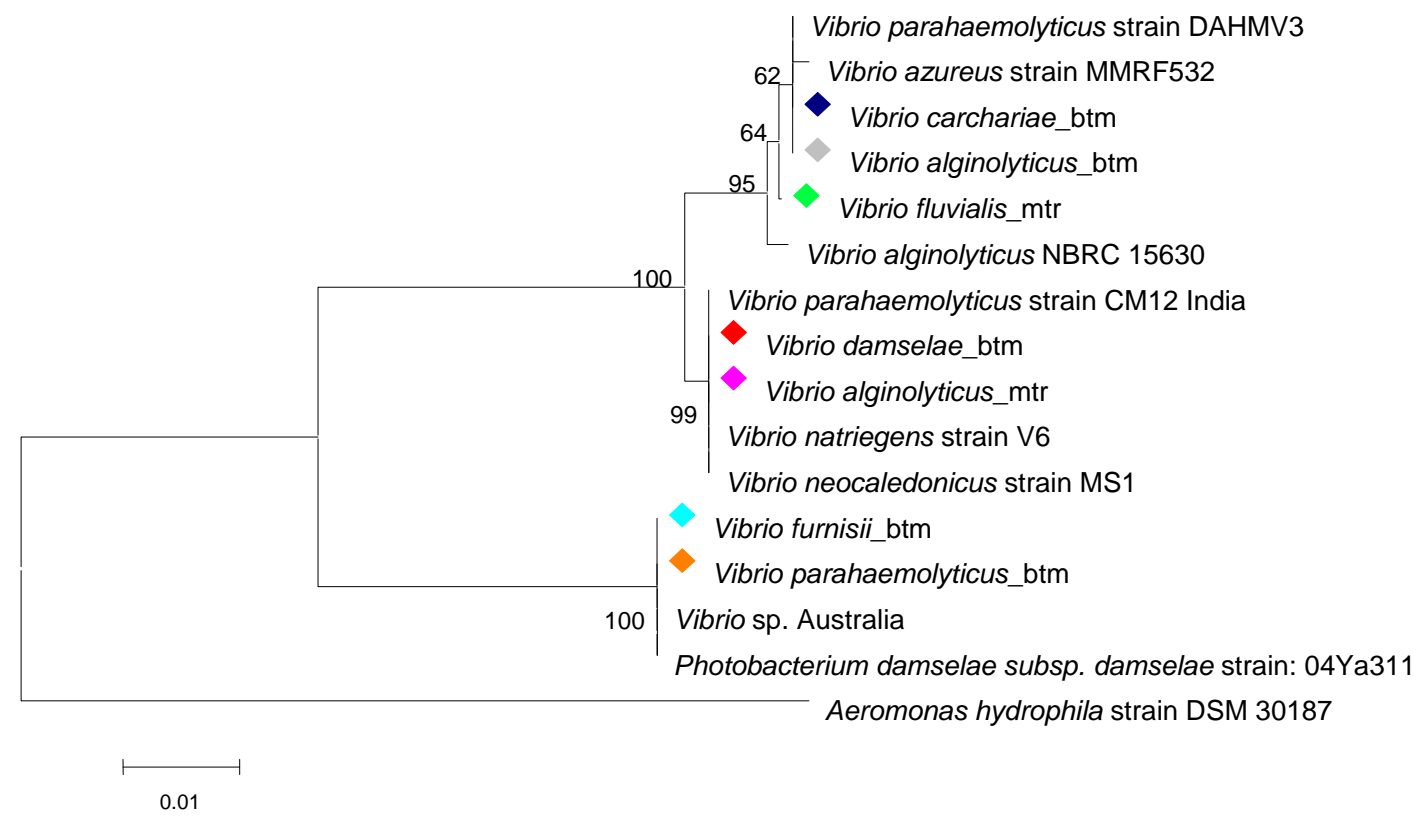

Fig. 2 Phylogenetic tree of Vibrio using neighbor-joining method.

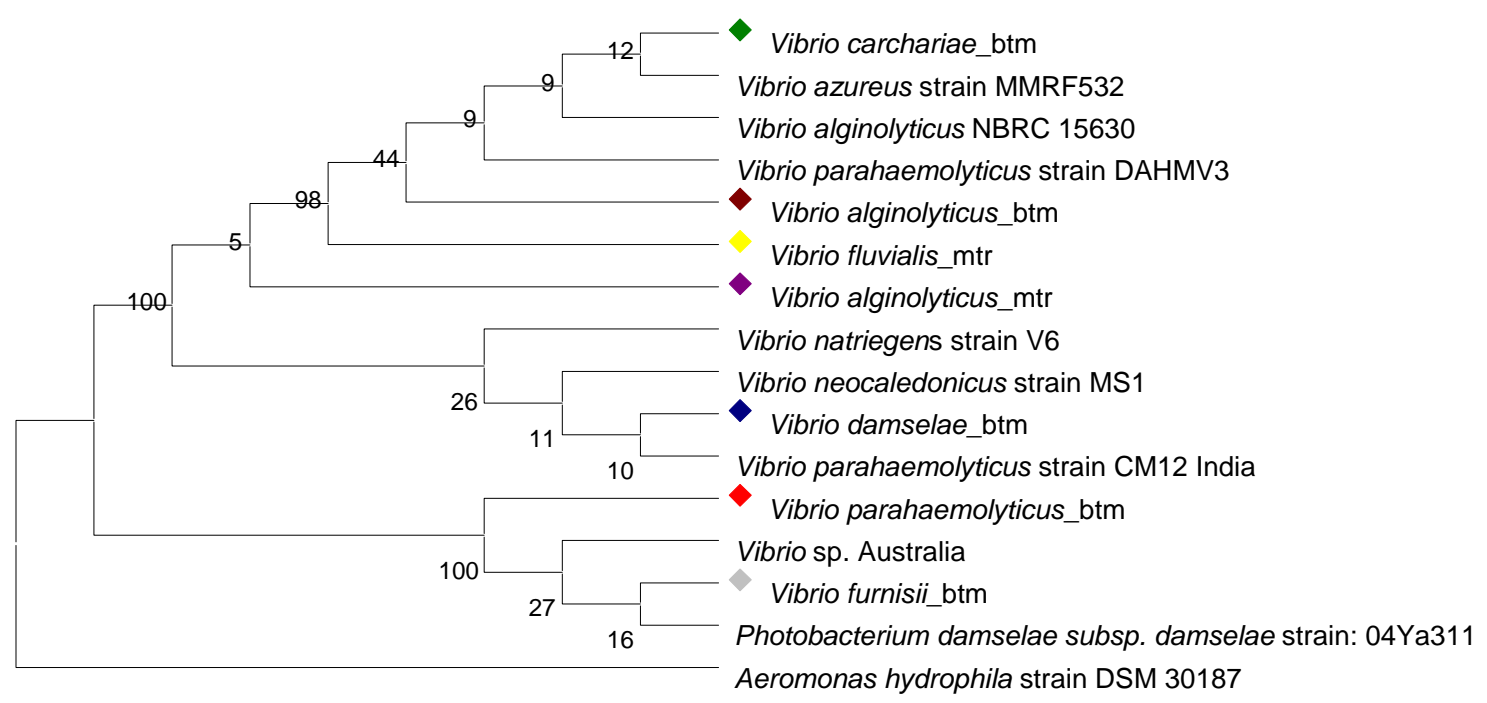

Fig. 3 Phylogenetic tree of Vibrio using maximum-parsimony method. 


\section{Conclusions}

Phenotypic identification from Batam were found six species of Vibrio, namely, $V$. alginolyticus, $V$. carchariae, $V$. damselae, $V$. furnisii, $V$. fluvialis and $V$. parahaemolyticus, and three species of Vibrio from Mataram, namely, V. alginolyticus, V. carchariae and $V$. fluvialis. On the other hand, phenotypic identification was not supported by molecular identification on 16S rRNA region. Therefore, it was suggested that phenotypic identification should be supported by molecular examination.

\section{References}

[1] Kordi, K. 2004. The Countermeasures of Pests and Fish Diseases. Jakarta: Rineka Cipta and Bina Adiaksara, 175.

[2] Austin, B., and Austin, D. A. 1987. Bacterial Fish Pathogens: Disease in Farmed and Wild Fish. England: Ellish Horwood Limited, 111-27.

[3] Suwanto, A. 1994. "Pulsed-Field Gel Electrophoresis: A Revolution in Microbial Genetic.” Aspac. J. Mol. Biotechnol. 2: 78-85.

[4] Amaral, G. R., Dias, G. M., Wellington-Oguri, M., Chimmeto, L., Campeao, M. E., Thompson, F. L., and Thompson, C. C. 2014. "Genotype to Phenotype: Identification of Diagnostic Vibrio Phenotypes Using Whole Genome Sequences.” Int. J. Syst. Evo. Microbiol. 64: 357-65.

[5] Austin, B., and Austin, D. A. 2007. Bacterial Fish Pathogens: Diseases of Farmed and Wildlife Fish, 4th ed.. Chichester, UK: Springer-Praxis Publishing, 552.

[6] Public Health England. 2014. UK Standards for Microbiology Investigations (SMI): Quality and Consistency in Clinical Laboratories.

[7] Felix, F., Nugroho, T. T., Silalahi, S., and Octavia, Y. 2011. "Screening of Indonesian Original Bacteria Vibrio sp. as a Cause of Shrimp Diseases Based on 16S Ribosomal DNA Technique.” Jurnal Ilmu dan Teknologi Kelautan Tropis 3 (2): 85-99.

[8] Edwards, D., Stajich, J., and Hansen, D. 2009. Bioinformatics: Tools and Application. London, New
York: Springer, 9.

[9] Thompson, J. D., Gibson, T. J., and Higgins, D. G. 1994. "CLUSTAL W: Improving the Sensitivity of Progressive Multiple Sequence Alignment through Sequence Weighting, Position-Specific Gap Penalties and Weight Matrix Choice.” Nucleic Acids Res. 22 (22): 4673-80.

[10] Kumar, S., and Gadagkar, S. R. 2000. "Efficiency of the Neighbor-Joining Method in Reconstructing Deep and Shallow Evolutionary Relationships in Large Phylogenies.” Journal of Molecular Evolution 51 (6): 544-53.

[11] Liu, X. F., Cao, Y., Zhang, H. L., Chen, Y. J., and Hu, C. J. 2015. "Complete Genome Sequence of Vibrio alginolyticus ATCC 17749.” J. Genome Announc. 3 (1): e01500-14.

[12] Nithyamand, P., Veera, R. A., and Kurutha, P. S. 2008. $16 S$ rDNA Sequence of Culturable Bacteria from the Coral Acropora digitifera from Gulf of Mannar. A Report, Alagappa University, India.

[13] Arboleda, M. D., and Reicardt, W. T. 2010. "Vibrio Causing Porites Ulcerative White Spot Disease.” Dis. Aquat. Org. 90 (2): 93-104.

[14] Cervino, J. M., Thompson, F. L., Gomez-Gil, B., Lorence, E. A., Goreau, T. J., Hayes, R. L., Winiarski-Cervino, K. B., Smith, G. W., Hughen, K., and Bartels, E. 2008. “The Vibrio Core Group Induces Yellow Band Disease in Caribbean and Indo-Pacific Reef-Building Corals.” $J$. Appl. Microbiol. 105 (5): 1658-71.

[15] Carson, J., Higgins, M. J., Wilson, T. K., and Gudkovs, N. 2005. Identification of Vibrionaceae from Australian Aquatic Animals Using Phenotypic and PCR Procedures. Victoria: AAHL Australian Fish Disease Laboratory.

[16] Chalkiadakis, E., Dufourcq, R., Schmitt, S., Brandily, C., Kervarec, N., Coatanea, D., Amir, H., Loubersac, L., Chanteau, S., Guezennec, J., Dupont-Rouzeyrol, M., and Simon-Colin, C. 2013. "Partial Characterization of an Exopolysaccharide Secreted by a Marine Bacterium, Vibrio neocaledonicus sp. nov., from New Caledonia.” J. Appl. Microbiol. 114 (6): 1702-12.

[17] Manju, S., and Vaseeharan, B. 2013. Screening and Characterization of Biofilm Forming and Probiotic Strains from Aquatic and Hospital Environments. A Report, Department of Animal Health and Management, Alagapa University, India. 